\title{
Humanitarian Aid and the Biafra War: Lessons not Learned
}

\author{
Marc-Antoine Pérouse de Montclos*
}

\begin{abstract}
In African contemporary history, Biafra is not only remembered as one of the worst humanitarian crises on the continent, but also as a tragedy that gave rise to the concept of ingérence or the international responsibility to protect. Unfortunately, the controversies about the impact of aid during the conflict have been forgotten. Today, the humanitarian legend of Biafra celebrates the saving of starving children and the birth of the famous NGO Médecins sans Frontières, but it does not acknowledge the military impact of relief operations that helped the secessionists continue the war for over a year after it was lost militarily. As it prolonged the suffering of local populations, relief was a matter of discussion during and just after the war. Since then, this strategic debate has been 'lost in translation'. This paper will argue that the contemporary idea of humanitarian aid that advocates a right of intervention in order to save innocents confuses the issue for at least two reasons. First, it leads us to think wrongly that Biafra gave birth to the concept of an international responsibility to protect, something that had existed previously. Secondly, it overshadows the dark side of humanitarian aid, where international intervention often assists belligerents rather than civilians, prolongs suffering, and poses new threats to national sovereignty.
\end{abstract}

\section{Résumé}

Dans l'histoire contemporaine de l'Afrique, on se souvient du Biafra comme l'une des pires crises humanitaires sur le continent, mais aussi comme une tragédie qui a donné naissance à la notion d'ingérence ou la responsabilité internationale de protéger. Malheureusement, les controverses sur l'impact de l'aide durant le conflit ont été oubliées. Aujourd’hui, la légende humanitaire du Biafra célèbre le sauvetage d'enfants affamés et la naissance de la célèbre ONG Médecins sans

* IRD (Institut de recherche pour le développement), 32 av. Henri Varagnat 93143 Bondy cedex FRANCE. E-mail: perouse@bondy.ird.fr. 
Frontières, mais elle ne reconnaît pas l'impact militaire des opérations de secours qui ont permis aux sécessionnistes de continuer la guerre pendant plus d'un an après qu'elle a été perdue sur le plan militaire. Alors qu'il prolongeait les souffrances des populations locales, le secours fut un sujet de discussion pendant et juste après la guerre. Depuis lors, ce débat stratégique a été « perdu à la traduction ». Cet article soutient que la notion contemporaine de l'aide humanitaire, qui défend un droit d'intervention pour sauver des innocents, complique les choses pour au moins deux raisons. Tout d'abord, il nous amène à penser à tort que le Biafra a donné naissance à la notion d'une responsabilité internationale de protéger, quelque chose qui avait existé auparavant. Deuxièmement, il éclipse le côté sombre de l'aide humanitaire, où l'intervention internationale assiste souvent les belligérants plutôt que les civils, prolonge la souffrance et pose de nouvelles menaces à la souveraineté nationale.

\section{Introduction}

In African contemporary history, Biafra is not only remembered as one of the worst humanitarian crises on the continent, but also as a tragedy that gave rise to the concept of ingérence, or the international responsibility to protect. Unfortunately, the controversies about the impact of aid during the conflict have been forgotten. Today, the humanitarian legend of the Biafran crisis focuses on the role of people like Bernard Kouchner, currently the French Minister of Foreign Affairs, and the birth of the famous NGO Médecins sans Frontières, which was awarded a Nobel Prize in 1999.

This stereotype does not acknowledge, however, the military impact of relief operations that helped the secessionists to resist and carry on the fighting. Port Harcourt fell into Nigerian hands one year after an independent Republic of Biafra was proclaimed by Lt General Odumegwu Ojukwu in May 1967. From then on, the secessionists were completely surrounded and had no further access to the sea. From a military point of view, they were finished. In Port Harcourt, they had lost the war rather than simply losing a battle. Yet their fighting continued until January 1970 thanks to the support of humanitarian organizations that provided vital supplies to the Biafran Army. As it prolonged the suffering of local populations, relief was a matter of discussion during and just after the war. Since then, this strategic debate has been 'lost in translation'. Nowadays, the heroic resistance of the Biafrans is analyzed as a result of the disorganization of the Nigerian Army, the successful tactics of the secessionists and/or the determination of a people struggling for survival. The part played by humanitarian aid is reduced to the attempts to break the blockade and to advocate a right of intervention in order to save starving children. Such a vision confuses the issue for at least two reasons. First, it lets us think wrongly that Biafra gave birth to the concept of an 
international responsibility to protect. Secondly, it overshadows the dark side of humanitarian aid.

\section{The Responsibility to Protect and State Sovereignty: An Old Issue}

Historically, the international concept of a responsibility to protect was not born out of the Biafran crisis. It existed before, elsewhere and in other ways, for instance, when the French Army invaded Lebanon to protect Christian communities against their Druze oppressor in 1860. Backed by European powers, such an intervention d'humanité was already linked to gunboat diplomacy, as humanitarian interventions of today often have a military component, from Afghanistan to D.R. Congo. Colonial motives were of course different from operations that now aim to impose peace on behalf of the international community. But humanitarian rhetoric was always an argument of foreign policy. Indeed, Africa was colonized under the pretext of civilizing the continent and abolishing the slave trade (Verges 2001).

In this regard, the Biafran crisis was only a step towards the formalization and modernization of the concept of the responsibility to protect. At the end of the 1960s, the Cold War and the superpower rivalry did not allow the United Nations to circumvent state sovereignties and to organize peace enforcement operations without the consent of all. So humanitarian actors had to rely on themselves and the media to break up the Nigerian blockade against the secessionists. This kind of advocacy was not completely new. The Boer War in 1901 had already been a major case for humanitarian relief (Thompson 2002). According to Andrew Thompson, the amount of money collected for the British in South Africa was even higher than the funds raised by the Live Aid show during the famine in Ethiopia in $1985 .{ }^{1}$ Yet that was for white victims only. The Ethiopians invaded by the Italian Fascists in 1936 or the Congolese at independence in 1960 got almost nothing. The real innovation of the Biafran crisis was worldwide humanitarian mobilization for Black Africans.

The mass starvation of Biafrans in 1968 thus played a crucial role. For the first time, photographs of emaciated children started to circulate widely. Humanitarian actors also became more vocal and campaigned against the deadly Nigerian blockade. A young doctor of the Red Cross, Bernard Kouchner, refused to keep silent and stay neutral. He violated the internal rules of the ICRC (International Committee of the Red Cross), which had the greatest difficulties in being allowed to operate within the Biafran enclave. Horrified by what he had seen, Kouchner went back to France, raised the issue to the media and denounced what he called a genocide. The Biafrans, he said, were starving, the international community was doing nothing about it and the Nigerians forbade NGOs to deliver food to the secessionists. He believed 
that the use of hunger as a weapon of war was indeed genocide, even if the Igbo were not to be massacred after their defeat in 1970. For Kouchner and many others, the Nigerian blockade represented a Muslim plot to finish the pogroms of 1966 and eliminate a Christian people. The story was relayed by the French secret service, which used the genocide propaganda to raise support for the Biafrans in order to break up an Anglophone giant within Francophone Africa (Glaser and Smith 2005:67). Such politicization of a humanitarian crisis is a classic situation, and is reminiscent of the current American rhetoric of genocide in Darfur to mobilize the international community against the Sudanese Islamic military junta.

\section{Humanitarianism and the Biafran Economy of War}

From a media point of view, Biafra was a success story, the first major famine to be addressed through media images of starving Africans, before Ethiopia in 1984 or Somalia in 1992. But from a humanitarian point of view, it was an operational disaster, a logistical nightmare and a political failure. Professionals know that a fundamental dilemma of relief organizations is that they help combatants while trying to assist war victims. Aid exacerbates conflicts because it feeds militants, sustains their dependants, supports war economies and provides legitimacy to belligerents (Lischer 2005:6). And all of this happened in Biafra. Aid legitimized the struggle for independence of Christian Igbo who were portrayed as victims of a genocide. It also helped the rebels to be supplied with food and weapons. This was because humanitarian logistics in war zones usually follow the same routes and means of transport as the military (Nordstrom 2004). Planes that supplied Biafra from São Tomé carried both food and weapons. Other humanitarian hubs like Peshawar for Afghanistan after 1980 or Lokichokio for southern Sudan after 1989 are also known to have provided 'freedom fighters' with fresh supplies. Biafra was no exception to such a problem. The strategic contribution of relief to the Biafran war economy was twofold: logistical and financial.

To start with, planes were a vital link to the outside world after the last Biafran access to the sea, Port Harcourt, fell in May 1968. Humanitarian organizations, especially the Catholic Caritas and the Scandinavian Protestant Churches, were instrumental in setting up an air bridge from São Tomé. Unlike the ICRC, they worked only on the Biafran side, so they did not have to bother with the Nigerian Government. The Norwegian Church Relief, for instance, decided to circumvent the Federal authorities because Lagos did not allow it to supply the enclave and had diverted one of its food cargoes to Santa Isabel, now the capital city of Equatorial Guinea. ${ }^{2}$ After a secret visit to Lisbon, the organization's general secretary, Elias Berge, began to send provisions from the Portuguese island of São Tomé in the planes of an 
American adventurer, Hank Wharton, who carried weapons for the Biafrans. By loading food onto these planes whenever there was space available, the Norwegian Church Relief opened itself to the charge of being involved in arms-smuggling. But it justified the violation of the Nigerian airspace because the blockade was an illegitimate weapon of war and could therefore be broken.

With its Danish, Swedish and Finnish counterparts, the Norwegian Church Relief eventually participated in August 1968 in the creation of Nordchurchaid, an ad hoc organization in collaboration with a company based in Reykjavik, Flughjalp ('Aid by Air'), to send food to São Tomé. From here, relief was then transported to Biafra by a consortium of some thirty European and American NGOs, the Joint Church Aid (JCA), which was nicknamed 'Jesus Christ Airlines'. Their clandestine planes flew by night in very difficult conditions, and three of them were destroyed by Nigerian bombs. The Norwegian Church Relief funded two million out of a total of seven million dollars spent during these operations, which were joined in June 1969 by secular organizations like Oxfam, Save the Children and the ICRC. Interestingly enough, the 'Jesus Christ Airlines' was headed up from August until September 1968 by Carl-Gustaf Von Rosen, a Swedish count who was to rebuild the Biafran Air Force in May 1969. Internal rules of Nordchurchaid did not mention the prohibition of weapons, and the cargo included spare parts for trucks that were supposed to deliver food within the enclave, but could also transport troops (Lloyd 1972). The military support was obvious. To continue receiving weapons and planes, the Biafrans had only one airstrip, at Uli, and the JCA agreed to enlarge it to keep it operational, unlike the ICRC, which refused to do so (Wiseberg 1974). At the end of 1969, the situation was so dire that Odumegwu Ojukwu officially asked the relief agencies to supply his army. During distributions, it became more and more difficult to protect civilians from soldiers who tried to take food by force; aid workers had to hire armed guards to protect their stores from looting (Cronje 1972).

The relief support to the enclave war economy was not only material, but also financial. The secessionists lacked hard currencies because the introduction of new banknotes by the Federal government in January 1968 rendered valueless the millions of old Nigerian pounds still in Biafran hands. The creation of a Biafran pound was not a solution. It had no value outside of the enclave. Printed in Portugal, it was a paper money only, for it would have been too costly to mint and import coins. As a result, even Biafran banknotes were scarce, while plastic tokens were used as ersatz coins. Within the enclave, the population preferred to keep its cash at home because their accounts had been frozen by the local authorities and they risked being recruited by the military while going to the bank (Uche 2002). They tried to save Nigerian coins which, unlike banknotes, were still used on the Federal 
side and whose highest value was one shilling. With these coins, some smugglers succeeded in crossing the frontlines and importing goods on the black market. ${ }^{3}$ But the government of Odumegwu Ojukwu could not export anything to gain hard currency. Because of the Federal blockade, oil revenues did not materialize and no foreign private interests were willing to risk purchasing rights to exploit Biafran mineral resources. In order to be allowed to go inside the enclave, humanitarian organizations were the only ones to buy the local currency, and they provided for free the necessary supplies that fed the military.

Aid thus became crucial to prevent the collapse of the secession attempt. The Commander of the Biafran Army, Alexander Madiebo, admitted that they eventually lost the war because of a lack of money (Madiebo 1980). As a matter of fact, relief and mission organizations were the primary source of foreign exchange ( $£ 4.3$ million), followed by the French secret service ( $£ 2$ million) and donations from the Igbo diaspora overseas ( $£ 750,000)$, the Igbo in Nigeria $(£ 100,000)$ and various concerned citizens in the West $(£ 100,000)$ (Lindsay 1969). According to Odumegwu Ojukwu, 'the only source of income available to Biafra was the hard currency spent by the churches for yams and garri'. His Chief of Military Planning, Mike Okwechime, confirmed that 'financing the war was largely accomplished through private and humanitarian contributions. Much was diverted from funds raised abroad. Those who wished to make strictly humanitarian contributions could give to specific agencies but those giving to Biafra often didn't ask any questions, and the money could be used to purchase arms on the black market' (Stremlau 1977). Out of \$250 million of humanitarian aid to Biafra, it was estimated that 15 per cent was directly spent on military items. This was equivalent to the amount of hard currency spent on weapons by the Nigerian Federal Government during the whole of the war (Smilie 1985).

\section{Lessons not Learned}

Given its dubious deployment, the role of humanitarian aid became a matter of controversy. During the conflict, two points of views clashed (Okpoko 1986). On one side, the British government argued that the most efficient way to save lives was to shorten the war by letting the Nigerians win: incidentally, this was also the position of Winston Churchill when he forbade humanitarian aid to occupied Europe during the Second World War. On the other side, charities alleged that to stop their airlift would result in millions of deaths. But their position became irrelevant after the defeat of the Biafrans in January 1970, for there was no effort to carry through a genocide against the Igbos. It then appeared clear that the main funders of the JCA consortium, namely the Catholic Caritas and the Protestant WCC (World Council of 
Churches), were far from being neutral and had deliberately supported the rebels. Worse, they had prolonged the suffering of the population. Critics suggested that the initials WCC stood for 'War Can Continue'. Yet the humanitarian workers denied their strategic involvement and continued to claim they were apolitical. ${ }^{4}$ Most of them refused to admit any responsibility in the conflict. At best, an official of the WCC raised doubts about JCA 'because of its political effects ... which include exposing the churches to charges of prolonging the war and adding to the suffering of the people'. ${ }^{5}$ As we can see, humanitarian actors were more concerned about their reputation than about the military use of their aid.

Such an attitude is not peculiar to the Biafran crisis. In general, relief organizations are reluctant to accept their wrongs and the political implications of their work. 'Aspiring to good,' writes a specialist, 'humanitarians too often mute awareness that their best ideas can have bad consequences' (Kennedy 2004). Regarding Biafra, relief workers considered they had done their best. Some even minimized their strategic role. According to Dan Jacobs, the secessionists did not need any humanitarian cover for their arms imports. Planes loaded with weapons still landed at Uli when the ICRC and the churches suspended their air bridge for a while (Jacobs 1987). Of course, it is true that the secessionists would have tried to continue their struggle anyway, with or without humanitarian aid. They had not needed any foreign support to start fighting in 1967. From 1968 onwards, relief only strengthened their capacity to resist and helped them to carry on the struggle for independence. The basic argument was not that humanitarian aid alone could prolong conflicts. The real issue was to know whether relief did more harm than good.

The problem was not restricted to Biafra, and was found again in Ethiopia in the 1980s or Somalia and Southern Sudan in the 1990s (Pérouse de Montclos 2001). Since the end of the Cold War, it is even possible that the unwelcome side-effects of humanitarian aid became worse because belligerents could not rely any more on military support from the superpowers (DeMars 2002:206). In Liberia and Sierra Leone, combatants starved their own population to attract relief and divert it (Hoffman 2004). In Rwandese refugee camps in 1994, NGOs fed the criminals who had just committed genocide. In the rest of D.R. Congo, relief was not only diverted by the belligerents, it also sustained and exacerbated local corruption (Reed, Weiss and Mubagwa 2004:38). Actually, the problem became so acute that authors like Alex de Waal considered that 'most humanitarian aid in Africa is useless or damaging and should be abandoned' (de Waal 1997). Others thought that, at the very least, governmental and non-governmental organizations should be ready to suspend their relief operations when their assets are looted, aid is diverted by the combatants, humanitarian workers are kidnapped and they 
realize they are doing more harm than good. Stephen Stedman and Fred Tanner, for instance, recommended the development of standards that would allow refugee agencies 'to refuse to engage in situations that blatantly support warring groups’. The United Nations High Commission for Refugees, they wrote,

should have in its arsenal the option of refusal [...] and create a category of forced evacuation or hostage-taking that will signal to the Security Council and attentive public around the world that manipulation is occurring as it unfolds.

Crises could be divided into categories that would determine how to respond, continue Stedman and Tanner:

If a refugee flight was considered a forced evacuation or hostage-taking, then UNHCR's obligations would be diminished, and the organization would have a powerful tool for publicizing the manipulation (Stedman and Tanner 2003:185, 187).

In such a situation, the difficulty is to explain to the general public that humanitarian aid can do more harm than good and that it is sometimes better to stop it. Excessive media coverage and the politicization of relief do not help in this regard, for states and NGOs risk being accused of doing nothing. Because the humanitarian market is very competitive, aid is often implemented for the audience rather than for the victims. As long as the show can go on, private and governmental funders do not care much about its negative impact. David Sogge explains:

Alleviating poverty and relieving victims of crisis, empowering community groupings and women, and casting spotlights on chronic wrongs and conflicts: these are among the main purposes private aid agencies set for themselves. Many assume they are making good these claims. Funds have been kept flowing on that promise. No agency seems to quit the field, and more agencies professing such purposes enter it every year. Yet this may reflect not the strength of performance, but one of greatest weakness: funding is only poorly linked with actual outcomes - if it is linked at all. Agencies are rewarded chiefly for spending and being active; they are almost never punished when that spending and those activities come to nothing, or entail unwelcome side-effects (Sogge 1996:16).

Theoretically, NGOs are supposed to stop their programmes when they cannot prove a causal link between their work and an improvement of the situation (Spar and Dail 2002:4). The reality is quite different. In most cases, NGOs quit the field for other reasons. According to a poll of 2,000-plus individuals, one humanitarian worker out of five mentions being evacuated because of insecurity (Buchanan and Muggah 2005). Lack of funding is another factor. But in general, NGOs are quite reluctant to leave. Their 'relief culture' explains this attitude. Historically, some of the most famous 
humanitarian NGOs have precisely been founded to protest against military blockades: Save the Children in Germany in 1919, Oxfam in Greece in 1942 or Médecins sans Frontières after Biafra in 1971. Today, they often protest when governmental organizations threaten to stop aid because of a lack of feasibility or political motives, as with the British DfID (Department for International Development) in Sierra Leone (Marriage 2006:19). For humanitarian workers, it is unethical to trade the saving of lives now for the potential saving of lives in the future. Faced with a Catch-22 situation, some argue that diverted aid is not likely to result in measurable development, yet the recipient country would fail without continued donor support.

The hypothesis of such a school of thought is that foreign relief is indispensable for the survival of the victims. Recipients would be incapable of coping with their fate if not supported. Yet the problem remains that we don't really know if Africans would be better with or without emergency aid. Relief organizations tend to ignore or even erode local capacities (Juma 2002). Regarding Biafra, we simply don't know what the situation would have been without the rescue operations. It is very possible that a longer interruption of the humanitarian air bridge could have helped the Nigerian Army to crush the rebellion sooner ... and save hundreds of thousands of lives instead of prolonging the conflict. This is exactly what the United States and the United Kingdom did during the Second World War: Winston Churchill was convinced that only a military victory could relieve suffering. He promised 'sweat and blood' and forbade aid to occupied Europe.

\section{Relief and Social Responsibility}

Because we cannot rewrite history, we have to admit our ignorance about the 'best' humanitarian solution for Biafra. The fundamental problem of relief organizations is that they do not even admit their political responsibility in conflicts. As a result, they hardly acknowledge the possibility of stopping their operations when they do more harm than good. In its Manual for Practioners, the United Nations Office for the Coordination of Humanitarian Affairs (OCHA) devotes only three lines to the problem: 'if non-compliance with the agreements results in an operating environment which compromises humanitarian security, consider, as a last resort, suspension of humanitarian activities until a conductive ... operating environment is re-established' (McHugh and Bessler 2006:82).

The Charter of the Sphere Project, an NGO initiative to create minimum humanitarian standards, is as elusive. It acknowledges 'that the attempt to provide assistance in situations of conflict may potentially render civilians more vulnerable to attack, or may on occasion bring unintended advantage to one or more of the warring parties'. But it does not say how to minimise 
such adverse effects and it does not set any benchmark to stop sending relief. If we are to believe the fine wishes of this Charter, 'it is the obligation of warring parties to respect the humanitarian nature of such interventions' (Sphere Project 2000). How to compel combatants to do so remains a mystery.

All sorts of phony arguments have been raised to condemn the possibility of stopping rescue operations when they do more harm than good. In Rwandan refugees camps in Zaire in 1994, for instance, some rationalized that if the Hutu fighters did not receive aid, they would steal it from the civilians. In other words, it was better to feed war criminals even if that helped them to resume the genocide! The same line of argument was used for military dictatorships like that of Siyad Barre in Somalia. Some authors claimed that the reduction of aid at the end of the Cold War was a major factor in the eruption of civil strife in the Horn of Africa (Laitin 1999). According to David Laitin, it precipitated the fall of Siyad Barre because the regime had no more resources to share in order to maintain its social base.

But such an analysis overshadows the other factors behind the civil war in Somalia, such as clan divisions, drought and arms proliferation. Moreover, the time frame did not confirm its conclusion: the opposition did not wait for a reduction in aid flows before opting for armed struggle. On the contrary, the troops of Siyad Barre bombed Hargeisa in 1988, when foreign assistance was still very significant. At this time, humanitarian aid for the Somali refugees of the Ogaden war of 1977 provided a major funding resource for the regime; the UNHCR alone injected the equivalent of 40 per cent of the state budget. Foreign assistance thus strengthened the dictatorship and delayed its fall. After the departure of Siyad Barre in 1991, other authors then argued that the diversion of aid by combatants supplied local markets, reduced food prices and defused confrontation for scarce resources (Auvinen and Kivimäki 2000:219). Still, humanitarian aid also brought new motives of competition and provoked conflicts for its control (de Waal 1994).

All in all, the fundamental issue is to assess the effects of relief in a war economy. On one side, humanitarian organizations claim to have a major impact on relieving suffering. On the other, they deny or minimize their political role in sustaining conflicts. The contradiction is obvious. Regarding southern Sudan, for instance, Oystein Rolandsen argued that the SPLA (Sudan People's Liberation Army) diverted little food after distribution, so it would have been useless to threaten to stop aid in order to encourage the guerrillas to protect civilians and to respect international humanitarian law (Rolandsen 2005:132). But the very same author drew attention to the strategic importance of relief when the movement of John Garang lost its rear bases in Ethiopia in 1991 and had to rely on foreign assistance to feed its combatants within southern Sudan. 
Eventually, our ignorance of the real impact of relief should advocate a principle of caution. Like transnational corporations, non-governmental and governmental relief organizations need to exercise social responsibility in war economies. They sometimes bribe corrupt leaders to gain access to victims (Ewins 2006:87). And they directly assist combatants when they provide means of transport and infrastructure such as airstrips. Roads built by the British Save the Children Fund in Ethiopia in the 1980s, or by the French ACTED (Agence d'Aide à la Coopération Technique et au Développement) in Afghanistan in the 1990s, are known to have been used by the military to reach remote areas and extend the fighting. From Burma to Angola, Nigeria or Sudan, humanitarian organizations criticize oil companies because they support dictatorships by paying taxes and allowing soldiers to use their planes or their cars. Yet relief actors are faced with the same challenge. As they follow the routes already used by troops and arms smugglers, they raise a similar issue to the corporate problem of tax evasion and money laundering, which point to the same offshore banking centres. In both cases, the same logistical or financial channels have criminal and legal purposes.

Of course, foreign direct investment and humanitarian inputs do not carry the same weight. Following the story of David and Goliath, public opinion usually favours 'small' NGOs as against 'big' governments or 'giant' transnational corporations. Some authors thus argue that private voluntary organizations do not have to be accountable because they are 'poor' and do not bear the same responsibility as, say, Shell or the World Bank (Bendell and Cox 2006:114). In other words, NGOs can criticize the lack of accountability of transnational corporations and international financial institutions; yet they do not need to be responsible to the communities they claim to help, empower and represent. Such double standards are difficult to accept (Pérouse de Montclos 2007). To have a charitable and non-profit motive does not exempt humanitarian workers from their social responsibility. In war-torn countries, the problem is even worse because it can contradict the aim of saving lives, not to mention its potentially negative effects on state capacity and sovereignty, which are even more essential to long-term security for local populations.

\section{Notes}

1. Organized by Bob Geldof, the lead singer of the Boomtown Rats, the Live Aid concert gathered famous rock stars like Paul McCartney, Mick Jagger, Bob Dylan, Elton John, Phil Collins and Crosby, Still, Nash \& Young. Thanks to the media, it raised a hundred million Euros in July 1985: a worldwide record before the Asiatic tsunami of December 2004. 
2. More details and references on foreign NGOs involved during the Biafran crisis, from Oxfam to Norwegian Church Aid, are to be found in the database of AidWatch: http://www.observatoire-humanitaire.org/.

3. Interestingly enough, such war profiteers did not suffer much when the secessionists were defeated in 1970. Their wealth was accumulated in merchandise and was not seized when a federal decree compelled the Biafrans to exchange all their cash for a lump sum payment of twenty Nigerian pounds per person. Cf. A. Harneit-Sievers, Axel and S. Emezue,(2000) 'Towards a Social History of Warfare and Reconstruction: The Nigerian/Biafran Case', in I. Amadiume and A. An-Na'im, eds., The Politics of Memory: Truth, Healing and Social Justice, London: Zed Books, pp. 110-26.

4. This position was always contested by Lagos. As for the secessionists, they also suspected some relief agencies of being Federal spies because many Biafrans towns fell into Nigerian hands subsequent to the arrival of humanitarian organizations in the area.

5. Off the record, the debate was of course different. Mike Yarrow (1978), an American Quaker, reports that at a meeting in Rome on 8 November 1968, JCA officials realized that providing food to the Biafrans could prolong the war and involve more suffering.

\section{References}

Auvinen, J. and Kivimäki, T., 2000, 'Somalia: The Struggle for Resources’, in W. Nafziger, F. Stewart and R.Väyrynen, eds, War, Hunger, and Displacement, Vol. 2: Case Studies, Oxford: Oxford University Press.

Bendell, J. and Cox, P., 2006, ‘The Donor Accountability Agenda’, in L. Jordan and P. van Tuijl, eds, NGO Accountability: Politics, Principles and Innovations, London: Earthscan.

Buchanan, C. and Muggah, R., 2005, Aucun répit sur les humanitaires : Etude de l'incidence de la violence armée sur le personnel chargé de l'aide humanitaire et du développement, Genève: Centre pour le dialogue humanitaire.

Cronje, S., 1972, The World and Nigeria: The Diplomatic History of the Biafran War, 1967-1970, London: Sidgwick \& Jackson.

DeMars, W., 2002, 'Transnational NGOs: the Edge of Innocence', in W. Nafziger and R.Väyrynen, eds, The Prevention of Humanitarian Emergencies, Basingstoke: Palgrave.

de Waal, A., 1994, 'Dangerous Precedents ? Famine Relief in Somalia, 1991-1993', in J. Macrae and A. Zwi, eds, War and Hunger: Rethinking International Responses to Complex Emergencies, London: Zed Books, pp. 139-59.

de Waal, A., 1997, Famine Crimes: Politics and the Disaster Relief Industry in Africa, Oxford: James Currey.

Ewins, P. et al., 2006, Mapping the Risks of Corruption in Humanitarian Action, London: Overseas Development Institute.

Glaser, A. and Smith, S., 2005, Comment la France a perdu l'Afrique, Paris: CalmannLévy. 
Harneit-Sievers, A. and Emezue, S., 2000, 'Towards a Social History of Warfare and Reconstruction: The Nigerian/Biafran Case', in I. Amadiume and A. AnNa'im, eds, The Politics of Memory: Truth, Healing and Social Justice, London: Zed Books, pp. 110-26.

Hoffman, D., 2004, 'The Civilian Target in Sierra Leone and Liberia: Political Power, Military Strategy, and Humanitarian Intervention', African Affairs 103:211-26. Jacobs, D., 1987, The Brutality of Nations, New York: Alfred A. Knopf,.

Juma, M. K., 2002, 'The Political Economy of Building Local Capacity', in M.K. Juma and A. Suhrke, eds, Eroding Local Capacity: International Humanitarian Action in Africa, Uppsala: Nordic Africa Institute, pp. 159-82.

Kennedy, D., 2004, The Dark Sides of Virtue: Reassessing International Humanitarianism, Princeton: Princeton University Press.

Laitin, D., 1999, 'Somalia: Civil War and International Intervention', in B. Walter and J. Snyder, eds, Civil Wars, Insecurity, and Intervention, New York: Columbia University Press, pp. 146-80.

Lindsay, K., 1969, 'How Biafra Pays for the War', Venture: Journal of the Fabian Colonial Bureau (London) 21(3): 26-7.

Lischer, S. K., 2005, Dangerous Sanctuaries: Refugee Camps, Civil War and the Dilemmas of Humanitarian Aid, Ithaca, NY: Cornell University Press.

Lloyd, H. et al., 1972, The Nordchurchaid Airlift to Biafra, 1968-70: An Operations Report, Copenhagen: Folkekirkens Nodjaelp.

Madiebo, A., 1980, The Nigerian Revolution and the Biafran War, Enugu: Fourth Dimension.

Marriage, Z., 2006, Not Breaking the Rules, Not Playing the Game: International Assistance to Countries at War, London: Hurst.

McHugh, G. and Bessler, M., 2006, Humanitarian Negotiations with Armed Groups: A Manual for Practitioners, New York: United Nations, Office for the Coordination of Humanitarian Affairs.

Nordstrom, C., 2004, Shadows of War, Violence, Power, and International Profiteering in the Twenty-first Century, Berkeley: University of California Press.

Okpoko, J., 1986, The Biafran Nightmare: The Controversial Role of International Relief Agencies in a War of Genocide, Enugu: Delta.

Pérouse de Montclos, M.-A., 2001, L'aide humanitaire, aide à la guerre ?, Bruxelles : Complexe.

Pérouse de Montclos, M.-A., 2007, « La face cachée des ONG », Politique internationale 116:347-68.

Reed, S., Weiss, H and Mubagwa, M., 2004, Evaluation of USAID's Humanitarian Response in the Democratic Republic of the Congo, 2000-2004, Washington, DC: U.S. Agency for International Development.

Rolandsen, O., 2005, Guerrilla Government: Political Changes in the Southern Sudan during the 1990s, Uppsala: Nordika Afrikainstitutet.

Smillie, I., 1985, The Land of Lost Content: A History of CUSO (Canadian University Service Overseas), Toronto: Deneau. 
Sogge, D., ed., 1996, Compassion and Calculation: The Business of Private Foreign Aid, London: Pluto Press.

Spar, D. and Dail, J., 2002, 'Of Measurement and Mission: Accounting for Performance in Non-Governmental Organizations', Chicago Journal of International Law 3(1).

Sphere Project, 2000, Humanitarian Charter and Minimum Standards in Disaster Response, Oxford: Oxfam, online at: http://www.sphereproject.org.

Stedman, S.J. and Tanner, F., eds., 2003, Refugee Manipulation: War, Politics, and the Abuse of Human Suffering, Washington, DC: Brookings Institution.

Stremlau, J., 1977, The International Politics of the Nigerian Civil War, 19671970, Princeton: Princeton University Press.

Thompson, A., 2002, 'Publicity, Philanthropy and Commemoration: British Society and the War', in D. Omissi and A. Thompson, eds, The Impact of the South African War, New York: Palgrave, pp. 511-27.

Uche, C., 2002, 'Money Matters in a War Economy: The Biafran Experience', Nationalism \& Ethnic Politics 8(1):29-54.

Vergès, F., 2001, Abolir l'esclavage: une utopie coloniale: les ambiguïtés d'une politique humanitaire, Paris: Albin Michel.

Wiseberg, L., 1974, 'Humanitarian Intervention: Lessons from the Nigerian Civil War', Human Rights Journal 7(1): 61-98

Yarrow, M., 1978, Quaker Experiences in International Conciliation, New Haven, CT: Yale University Press. 